the only remaining founder member. Of his more general services to science may be noted his work as general secretary of the British Association (18951900) and as president of the Dundee meeting in 1912, and his presidency of the Royal Society of Edinburgh since 1929. Sir Edward was elected a fellow of the Royal Society of London so long ago as 1878. He received a Royal medal in 1902 "for his researches into the functions and minute structure of the central nervous system, especially with regard to the motor and sensory functions of the cortex of the brain", while in 1924 he was awarded the Society's supreme honour, the Copley medal. In making the presentation of the Copley medal, Sir Charles Sherrington described Sir Edward's fundamental work on the adrenal and pituitary glands as opening up a modern chapter of physiological knowledge with important consequences for medical studies and treatment.

\section{China and American Scientific Expeditions}

By favour of Dr. Henry Fairfield Osborn, president of the American Museum of Natural History, we have received a copy of his reply to the communication from the Chinese National Committee for the Preservation of Antiquities in reference to the Museum's expedition to Inner Mongolia and the rupture in the relations for scientific co-operation between the Museum and Chinese scientific men (see Nature, 130, 803, Nov. 26, 1932). In his reply Dr. Osborn points out that the American expedition has worked under an agreement made in 1921 whereby, provided its operations were confined to regions where the Geological Survey of China could not work, it was to be unhampered in Mongolia; but, he maintains, the Geological Survey has not adhered to its part of the bargain. In 1928 the expedition's collections were detained at Kalgan for six weeks, without legal or moral right; and the expedition was charged with possessing only "hunting permits", although the permits were the same as in preceding years and the character of the work on which the expedition was engaged was universally known. In 1929 the expedition was not allowed to proceed in the field as the demands made by the Chinese commission were "exorbitant and without international precedent".

In the Chinese communication, it will be remembered, stress was laid on the fact that Dr. Andrews had assured the commission that the expedition of 1930 was to be the last of the series, but that in 1931 he had applied for a permit for further work in Mongolia. Here Dr. Osborn states that further work had been made necessary by the discoveries of the expedition in 1930 and the negotiations were opened at his request; yet Dr. Andrews was not even given an interview. He then deals with the termination of the Museum's work in China and the transfer of its activities to Manchukuo, a decision which was reached after mature deliberation. Further, he points out, the closure of the Museum headquarters at Peking by Dr. Andrews was not unauthorised, as has been suggested, but was effected with full authority as the officer of the Museum in charge of exploration and under direction. In expressing the regret of the American Museum that the friendly relations between Chinese scientific men and the American Museum, which existed until 1928, should be thus severed, Dr. Osborne feels that it is through no fault on the side of the Museum. Dr. Andrews insisted on the privilege of completing the work in Mongolia under the agreement of 1921. This made him unpopular with the commission, but no other course was open to him. Dr. Osborn concludes, "It is difficult to see how it would be profitable for this Museum to conduct field work under any other conditions."

\section{Technocracy}

RECENTLY in the United States the new economic doctrine of 'Technocracy' has aroused much attention and provoked much discussion. This movement has been sponsored by a number of engineers and scientific workers, and according to an article in the Times on January 5, its underlying thesis is that the tremendous technological advance made in industrial processes during the past century and particularly during the past twenty-five years has rendered all existing social and economic mechanism obsolete and futile. 'Technocracy' claims that scientific discovery and modern engineering skill have now armed mankind with powers that would ensure leisure and plenty for all if only they were properly employed. It asserts that the basic factor in social life is the amount of energy available for productive purposes and that no solution is possible so long as the present price system is retained. Energy, according to the exponents of 'technocracy', is the real measure of human labour and human wealth and therefore real prosperity will only be obtained when individualism is discarded and an entirely new system of distribution based on 'energy certificates' instituted. At present, however, as the Times article states, the highly technical language in which most of its statements are shrouded make certain aspects of the theory obscure while others could be refuted by any economist without difficulty. The lines of research and the deductions drawn from the assembled facts are obviously the work of engineers thinking in terms of mechanical production and ignoring all considerations of human psychology.

\section{British Industries Fair}

THE 1933 British Industries Fair, which opens on February 20 and continues until March 3, will be held, as last year, at Olympia and the White City in London, and at Castle Bromwich in Birmingham. It still goes on expanding. This year the Fair will be bigger, the exhibits more varied and the exhibitors more numerous than ever before. What is perhaps of more importance is that all indications up to the present point to the probability of a great increase in the number of buyers who will attend. For example, the acceptances by overseas buyers of invitations issued by the Department of Overseas 
Trade, which organises the Fair, are already 30 per cent more numerous than those received last year. Sixteen European countries, as compared with only five countries last year, are providing special travelling facilities at reduced rates to encourage their buyers to attend the Fair. Altogether some fifty-six different countries and territories will be thus represented. The Fair may be expected to show in what ways and to what extent British manufacturers have availed themselves of the competitive advantages obtained through Britain's abandonment of the gold standard and as a result of the Ottawa Conference. We hope to deal with scientific aspects of the Fair at a later date, but it is satisfactory to note now that scientific and optical instrument makers will be well represented.

\section{Association of British Zoologists}

Dr. J. Gray was in the chair as president at the annual meeting of the Association of British Zoologists, which was held in the rooms of the Zoological Society on Saturday, January 7. The morning session was given to discussion of several motions concerning the teaching of biology. It was moved by Prof. E. W. MacBride that vacation revision courses at the universities are highly desirable for teachers of science in schools. This motion was supported by several speakers, but the danger that such courses should be considered sufficient substitute for previous training in the sciences which the teacher was expected to teach was emphasised by Prof. W. Garstang and Prof. Graham Cannon. Mr. H. R. Hewer gave an account of the proceedings of the recent National Conference on the Place of Biology in Education. It was suggested by Prof. Douglas Laurie and Prof. J. S. Huxley that in elementary education a general scientific course is required rather than one in which the scientific subjects are separately organised, but that in such a general course biology must have a leading part. A discussion on the best way of influencing the teaching of biology in schools was introduced by Prof. Graham Cannon. He suggested that this could best be done through the examination boards of the country and in this was supported by Dr. Philippa Esdaile. The president suggested that many of the present difficulties are due to the absence of any body with the function of correlating school and university teaching.

Dr. GraY spoke on "The Importance of Zoological Advice to the State". He said that although the supply of biologists has greatly increased in recent years, there is still great difficulty in persuading good students to undertake work in Government employ. $\mathrm{He}$ considers this is partly due to the absence of liaison between the teachers at the universities and those who would later employ the biologists. Some body which could undertake the maintenance of this liaison would be useful. In the afternoon, Mr. W. B. Alexander spoke on the conduct of British ornithological surveys and mentioned the proposed founding of an Institute of Ornithology to deal with such subjects. Several speakers joined in the discussion of a motion introduced by Prof. F. Balfour Browne concerning the confusion in systematic zoology which results at present from the frequent change of zoological names necessitated by the strict application of the law of priority to them and from the small number of nomina conservanda which the International Commission on Nomenclature is able to set up. It was agreed by 23 votes to 3 "that British zoologists should at once set about making a list of proposed nomina conservanda, and that to this end a committee of zoologists should be constituted".

\section{Earthquake in the North of England}

AN earthquake, rather strong for England, occurred at about 8.30 A.M. on January 14 . It has been suggested that it was one of the numerous earth-shakes felt along the Irwell Valley fault near Manchester rather than a genuine earthquake. It differed, however, both in intensity and disturbed area from these local shocks, the strongest of which so far known (that of November 25, 1905) only attained the degree 7 (Rossi-Forel scale) and disturbed an area of 144 square miles. So far as we can judge from the early reports, the earthquake of January 14 was strongest in and near Wensleydale, so that it may have been connected with the well-known Craven fault. At Hawes and the neighbouring village of Bainbridge, a few field-walls and chimney-pots were thrown down. The shock was felt over a wide area, from the Point of Ayre lighthouse in the Isle of Man to Whitby and Bridlington, as well as at Manchester, Altrincham, etc. The disturbed area must thus contain about 25,000 square miles. The earthquake was recorded at Stonyhurst and West Bromwich, but not at Kew Observatory.

\section{Recent Chinese Earthquake}

A VERY severe earthquake occurred in north-west China on December 25. From records at nine widely distributed observatories, the U.S. Coast and Geodetic Survey places the epicentre in lat. $40^{\circ} \mathrm{N}$., long. $98^{\circ} \mathrm{E}$. (Wire Report of Science Service, Washington, D.C., Dec. 27.) This point lies between the towns of Su-chow and An-hsi-chow, near the edge of the Gobi desert, about 300 miles north-west of the epicentre of the great earthquake of 1927. The earthquake must have been very destructive, but, owing to the isolation of the district, weeks may elapse before accounts arrive from the central area.

\section{The Institute for Advanced Study}

THe Institute for Advanced Study in the United States was founded in 1930 by a grant of $5,000,000$ dollars from Louis Bamberger and Mrs. Felix Fuld. Dr. Abraham Flexner, director of the Institute, has announced that it will be opened in the autumn of 1933, and will be housed temporarily in Fine Hall, the graduate mathematics building at Princeton University. Prof. Albert Einstein has accepted a life appointment as head of the Institute's School of Mathematics. Prof. Einstein will make his home at Princeton; he will be in residence at the 